\title{
Role of Information Technology to Choose Optimized Strategies in Management
}

\author{
Roshanak Kakasoltani \\ Azad university of Qaemshahr \\ Chalus, SSO Clinic
}

\author{
Einollah Deiri \\ Faculty of Azad University of Qaemshar
}

\begin{abstract}
This study analyzes the use of Information Technology (IT) in management accounting and also the potentials and drawbacks of adopting IT in management accounting. IT changes frequently and accounting standards remain for many years without any major change. IT and management accounting are vital to both small and large organizations. Accounting bodies and communities have instantly stressed the need for a shift in accountants' education by increasing the knowledge of information systems and IT knowledge. This paper examines the relationship between IT and management accounting. The past literature also indicates the potential of IT in management accounting that will simplify the calculation process and better presentable options of the business data for effective decision making. The literature findings also indicate that IT has major impact on the costs, as implementing IT will result in big spending on the technology hardware, software and IT personnel. The study also shows that IT can improve accounting department efficiency and produce result effortlessly, timely and accurately. Accountants are recommended special attention to this issue.
\end{abstract}

\section{Keywords}

Information technology, management accounting, budgeting, business decisions, system technology

\section{INTRODUCTION}

Information Technology (IT) is a powerful tool that can play a big part in making an organization's business a successful one. The world has recognized that the advent of internet computing would be very dominant and foremost in the near future. We can see the impact of the technology in many business areas such as trading, publishing, filming and many more. The IT and internet have provided the opportunity for organizations to offer their products to customers anywhere in the globe. However, the growth of IT and internet remain staggering, the large portion are untapped in accounting, especially management accounting.[1]

Management accounting provides information on the budget, capital investment status, pay back period etc. to the internal users and decision-makers. Many organizations have ignored the prominence of management accounting and focused only on financial accounting. The pivotal use of management accounting would be more significant for planning and control operations when it is incorporated with current IT.

Many accounting studies have incorporated Information Technology paper as part of the accounting program to introduce IT to future accountants. For example, Chartered Institute of Management Accountants (CIMA) has included many Information Systems subject in to their syllabus.

\section{RESEARCH PROBLEM}

Application of IT in management accounting is to provide some IT relevance in management accounting to improve the efficiency of decision-makers and to facilitate the management accounting information accurate and error-free. The IT based management accounting intends to provide information and insight to management and shareholders, who are in the position to decide the budgets, investments and long term planning with the help of management accounting. Application of IT in management accounting depends on individual organizations' vision and appropriate system or technology acquired. If the need for strong and structured technology is not installed, an organization can waste its capital investment on technology. As such, application of IT in management accounting would result in benefits to the organization depending on the technology applied. Essentially, the research problems are summarized as below:

1. Lack of awareness and understanding of technology available and suitable based on organization to be adapted in management accounting.

2. Lack of availability of internal expertise and consultant to suggest, evaluate and implement IT in management accounting.

3. The effect of IT in management accounting may not be realized in the increased profits because of hidden and indirect costs incurred.

4. The impact of application of IT in management accounting may not be realized in a shorter time due to different nature of business, chosen technology and management directions.

\section{OBJECTIVES OF THE RESEARCH}

The objectives of research are as follows:

1. To contrast and scrutinize the traditional management accounting approach and management accounting with IT.

2. To examine and review the potentials of application of IT in management accounting.

3. To assess the benefits of adoption of IT in management accounting to the organizations.

4. To review the impact of application of IT in management accounting.

\section{SCOPE OF THE STUDY}

Application of IT in management accounting is enormous growing. The introduction of IT in accounting especially financial and managerial accounting are irrefutable. IT is a large area to explore from home PCs to large systems, 
firewalls and internet. Thus, this study focuses on the relevant technology adapted to management accounting such as multimedia technology and management accounting using internet. Major focus is given to impacts and implications of application of IT in management accounting. [2]

\section{SURVEY OF LITERATURE}

Scot M. Boggs (2003) believed that digital technology have been changing since a decade ago where the personal computers (PCs), streamlining manuals and Local Area Network (LAN) not only have reached small organizations but also individual home users. He reckons that digital technology will brace users to collect information from one place to another and manipulate data by filtering, sorting, compiling and analyzing to produce necessary reports for decision making. He strongly believes that with the digital technology, the companies will be able to achieve more value at strategic end of business and spend less time in processing transactions. Consequently, there is lack of argument in this article pertaining to the mindset of the small organizations users towards the digital accounting. [3]

Glen L. Gray (2001) discussed concern in financial reporting using internet. While internet and Web based information will provide an advantage for companies, Glen queries the confusion arises between the users and users interpretations on what should be allowed and what should be avoided when it comes to the Web based reporting. The limitation of this article is that the aspect of management reporting on Web was not given much importance. The author should have given larger magnitude to management reporting on Web, as it is vital to the internal users in order for them not to make wrong decision and wrong investment. [4]

Moreover, the information system may enable the company to pursue a strategy of just-in-time (JIT) production. The change in strategy might in turn cause a change in management accounting. This is very likely as the purpose of management accounting is to produce information such as the evaluation of the success of strategies (Horngren et al., 2005).

Connor \& Martinsons (2006) commented that information technology is a precious assistance because they provide information for making decision. David Kay (2003) examines the investment on technology for organization on new support initiatives for customer service. The author indicates that there are many vendors to provide Return on Investment (ROI) analyzing tools and it is a handy tool that measures economy benefits from technology investment. He introduces balance scorecard for customer support technology, which will improve business process, improve products more effective, improve organizational capability and better-motivated staff. The limitation of this article is that the author failed to identify the degree of importance as well as comparison between business investment and ROI on the technology investment. This article also did not address in detail the IT platform to be adapted and the budgetary cost.

Nucleus Research (2003) examined the requirement of Public Services New Mexico to support the document management challenges such as regulatory compliance, customer service, high storage costs and slow document access for administration and accounting purposes. This article also lacks information in discussing how the reports are produced and forwarded to the management to access the productivity of the employee. [7]
Micheal Gilman (2003) discussed data mining technology and the importance of IT in providing higher efficiency resulting in improved business decisions. Past data or history data is the key to companies to be successful in investment. However, the author failed to highlight the technical requirements interm of application platform and knowledge required in order to employ the system.

Burns, J., Scapens, R. and Turley, S. (1996) discussed the current and future role of management accountant such as the commercial orientation and impact of IT on management accounting, and decentering accounting knowledge.

Guido Sacchi (2003) discussed the problem of effective management of IT that has moved from administering the technology to improving the business value of the technology. This article failed to identify the risks and drawbacks of the service-oriented technology such as high cost, high maintenance and high skilled workers requirement.

Kristi Urich (2003) discussed the automation to improve the total cost of ownership by relating to field force. The author introduces the mobile computing for the company's employees and predicts that more and more organizations are adapting to mobile applications. The author suggested that with this new technology, the use of paper and paper environment can be discarded and move the organization towards the paper-less environment and digital information. Choosing the correct system is essential to the organizations, as it will find balance between the need and cost. The limitation of the article is that the author failed to highlight the consequences of having paper-less environment to the legal matters. There was no clear evidence that the author has full proof mobile system that cannot be tempered or manipulated. [8]

Given that the link between financial and management accounting information is of higher importance in financiallyoriented management control systems than in technically oriented ones, this would - once again - call for an integrated rather than a separate accounting system design. Nevertheless, how and why changes towards a financially-oriented management control system also induce changes in the management accounting system has not yet been explored (Hemmer and Labro, 2008; Lambert, 2007; Ittner and Larcker, 2001). [9]

David Hurwitz (2003) discussed the challenges and opportunity of 21 st century IT and the rise of portfolio management in the IT world. Current IT is very complex and challenging to any IT executive and finding them spending large sum of money in technology. The author recommends that IT should adopt a structured, transparent and defensible investment planning methodology. The portfolio management is based on asset allocation models that analyze goals, risk levels costs and forecast returns. The limitation of the article is discussing the IT organization only and lack of information on implementation of Enterprise Portfolio Management system to other organizations. The article also did not contain benchmark on the usage of the system and feedback from the organization that have implemented the system. [10]

Lesley Meall (2004) discovered that upgrading systems to accommodate international accounting standards is costly, complex and time-consuming process but once necessary changes have been made, the business benefits extend beyond International Financial Reporting Standards (IFRS) compliance. The limitation of this article is that the author 
failed to explain the different standards applied by IFRS using international accounting. There was no discussion of the technology platform and technology skill needed for supporting the IFRS based system. [11]

Kim Smith (2002) focused on the effect of e-business/ecommerce as a current development in the audit and the role of the auditor in tackling internet e-com. The author claims that the auditor should perform the internet e-com audit as per any other audit of financial statements. Auditors need to acquire appropriate level of IT and e-com skills and knowledge to understand the potential impact on the financial statements. The author has left out the discussion of potentials of e-auditing in the e-com environment. The article also has not included comparison and different skills required by auditors to perform e-com audit and also conventional audit.

Carol Wong (2003) examined the efficiency and data consolidation using right and appropriate accounting application. Taking example of Audrey International Company, which have deployed new accounting system developed in-house by Dynamic Business Solution. The article draws the benefits and advantages achieved by the company after successfully implement the new accounting system. However, the author has not highlighted the cost of the system and the implementation cost for the accounting system. The article has limited discussion on the system development life cycle and how they deployed the new system. [12]

Dechow et. al., (2007) emphasized the importance of information technology in management control. IT in management accounting is about how companies manage and control their resources.

Colette Steckel (2003) studied how the individual can use his/her accounting background to kick-start the IT career industry. Based on the case study, the author initially discussed the IT market in China country and noticed that the software market is not on par as the hardware market. The research found that the China market needs world class IT technology integrated with the business. The author describes how an accountant took the opportunity available in the China market to develop financial analysis software. At that time, many companies in China were using only bookkeeping software and it does not satisfied the company's requirement. So, accounting and financial analysis software was found as a good opportunity in the market. The introduction of the financial analysis software was done in the year 2000 and notably the software was highly regarded. This article has not shown any evidence on the advantages and the benefits of the financial analysis software.

Paul Philips and David Kirby (2002) examined the impact of electronic business on accountants. The authors suggested that the accountants should understand the organization changes that need to take place and reposition themselves in the organization hierarchy where they can produce useful information for the formulation and the implementation of ebusiness strategies. The limitation of this article is that the authors did not specify the roles and responsibilities played by the regulatory and standard-setting bodies to groom accountants to meet e-business challenges.

Steve Skidmore (2002) discussed the involvement of Information Technology in the accounting curriculum. There is brief explanation on IT and accounting, where IT plays vital role in supporting activities of both profit-oriented and non profit-oriented organizations. Accountants apart from comprehensively using various types of information and technologies, they often play important managerial, advisory and evaluative roles in connection with adoption and use various information technologies by organizations of all types and sizes. The author compares the traditional accountant's role, where accountants have been entrusted with the task of evaluating investment in business systems, evaluating business system designs and reporting on potential weakness. Current accountants role have been changing to support the extensive organizational restructuring such technologies. Accountants must possess core IT skills and the accounting bodies should ensure that the candidates have IT skills before obtaining the accounting qualifications. The decision-makers should be included in the study, as they play vital role in deciding company's investment policies.

Welfle, B. and Keltyka, P. (2000) discussed the impact of globalization on the information requirement and inadequacy of traditional cost accounting to yield the information required.

Mike Couzens (2003) explained how web site can form an integral part of an organization. It is essential for a web site to be interactive, engaging clients and prospective clients. The web site therefore allows the company to strengthen personal relationship with client/prospective client. The author failed to discuss the weakness part of having web site such as the cost of developing web site and also maintaining cost. Web site may not suit all types of organizations, as some organizations prefer to use other methods to gain business advantages.

Anastas, M. (1997) discussed about the changing role of management accounting and financial management such as being an internal consultants and strategists, decision making team member, and initiating and implementing IT.

Marriott, Marriott \& Selwyn (2003) explored undergraduate students' use and attitude towards information communication technology in accounting courses at two UK universities. The internet is a rapidly changing area of education and, indeed, has caused some prominent commentators to argue that the researchers should only concentrate on the potential uses of this evolutionary medium rather than be concern with is present weaknesses. The limitation of this article is that the author did not discussed on the weaknesses of the internet, as there are many notorious information and pictures that could distract students.

Barry Cooper (2002) found out about the attributes of the accountants of the future. The author gathers the information from the accounting bodies to examine the drivers of change that will impact on the role of accountants in the future. The author fails to highlight the ways that accountants need to keep track with the IT changes. The article did not discuss the risks and barriers faced by accountants in adapting IT and changing traditional mind-set.

Andrew Collier (1999) explored the potential impact, and issues surrounding e-commerce and practicing accountants. The author accepts that e-commerce is a major area of growth over next few years and virtually every well retailer is developing some form of web presence. The limitation of this article is that the information of the e-commercial risks and disadvantages were not highlighted.

The computerization is changing management accounting system to become integrated with standardization \& 
routinization, localized and disseminated in an organization (Granlund, 2007). [13]

\section{RESEARCH METHODOLOGY}

This study was undertaken over a four weeks period and the main source of information retrieval was from internet and search engines such as Google, Yahoo, Hotmail and Catcha was used extensively to trace and refer online information and news. There were many articles, journals, vendor's white papers, analyst reports and various published materials gathered from the internet web sites such as knowledge storm, computer world, business today, Emerald-Library, Amazon, ACCA business and accounting and e-week. Journals and other printed materials such as Computer world, Information System Controls, Internet Magazine, Computer, Info Security Magazine, Business Week and Times was used for further reference. Based on the data and information collected, a research framework was developed as per Figure 1.

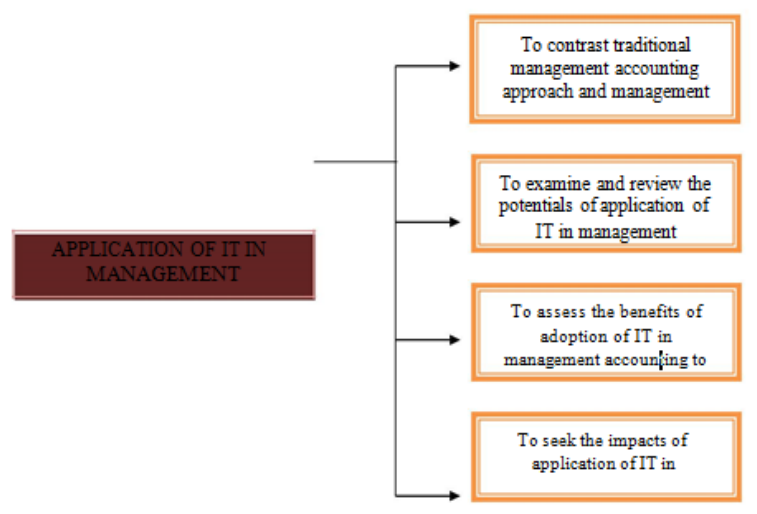

\section{Fig.1 Research Framework \\ 7. DISCUSSION, ANALYSIS AND FINDINGS}

Traditional Management Accounting vs. Management Accounting with IT.

Management accounting plays a major role in planning and decision-making functions in the management process. In order to discuss about traditional management accounting, let us look at traditional accounting, which concentrated on meeting legal and tax requirements. Traditional management accounting focused on manual collection of information or data of the industry or the competitor for the use of developing and monitoring the business strategies. Management accounting has usually been overlooked by many organizations due to its complexity to compile information for the internal users. In the beginning, traditional accounting software provided only bookkeeping facility and the information on breakeven point, standard costing and capital investment have to be derived by spending long hours.

The organizations' accounting function only focused on financial accounting; the shareholders only stressed on profit and loss statement. Management accounting was avoided because of the inaccuracy and time factors. Traditionally, consolidation of management accounting is done in the meeting room, where the representative of each department provided figures of operations, sales and inventories. The management reports were produced from information gathered from the meeting and submitted to the management for decision making. It was more difficult for multi-national companies, as they needed to group the staff around the globe. The accuracy and validity of the data was questionable and it took couple of weeks to produce the reports.

The traditional role of accountant was mainly to involve in budgeting and reporting for the organization. It was the accounts department's responsibility to present the budgeting and investment planning to the decision makers. The accountant should possess skills such as analytical skills to understand bookkeeping meticulously, statistical skills and report writing and presentation skills. The role of accounts department and accountant were limited and only focusing on organization's account functions.

Application of IT in management accounting has changed the perspective of traditional management accounting. In fact IT has been introduced in every aspect of industries from education to e-commerce. The introduction of IT in accounting has made management accounting to be more prominent to organization's internal users and decisionmakers. New technologies nowadays support management accounting together with financial accounting. It is prerequisite for accounting systems to have complete management accounting module incorporated, which include budgeting system, investment-planning system, standard costing system and stock control system packaged in one. The budgeting, planning and so on is created by the system itself and the depth of information provided depending on the capability of the technology adapted. Shareholders and investors very much rely on the management reporting to plan their investment. The force of internet has pushed the organizations to compete globally and take advantage of global market. Small companies no more have to fear large organizations in competing for business. As long as the internet is used adequately, the small companies will succeed in their business. Internet allows small companies to post the companies financial and management accounting in their Web site to create confidence of their potential customers. The IT helps management accounting to provide current internal information and analysis to support current decision making.

Application of IT in management accounting has changed the role and responsibilities of accountants. Management Accountants now have to shift their mind-set towards the technology and acquire the following skills:

- Computer skills,

- Data modeling,

- Making forecasting and projections,

- Developing assumptions and criteria,

- Strategic and looking forward,

- Technology-oriented,

- Creativity and adaptability,

- Strategy formulator and consultant.

Management accountants will play more dominant role in current and future business strategies with the introduction of technology based management accounting. The technology is changing the organizational structure and the business world; as such management accountants now have new height to focus, especially with changed performance measures. It is time for accountants to throw away the old thinking and adapt to new technologies. The technology has moved management 
accounting to new dimension and increases the need for management accounting for the organization's decision making. [14]

\section{APPLICATION OF IT IN MANAGEMENT ACCOUNTING - THE POTENTIALS}

Application of IT in management accounting has created excellent potential to the accounting system and now it is not possible or practical to perform accounting either financial or managerial without the help of IT. The organizations have acknowledged the potential of IT in management accounting and ready to explore the potentials to benefit the organizations. What is IT potential? Well, it is actually identifying the forceful reasons for adapting IT in management accounting.

IT made the future of any organization to compete in the global economy and IT provides the competitive advantage to reach customers anywhere in the globe. Every organization is either computerized fully or extensively. Management accounting also had to bow to the augment of technology and it is wise applying IT in management accounting. The technologies such as data mining and data warehousing becomes very valuable and drives application of IT in management accounting. Automation is a potential IT technology, which can be used in management accounting to automate the data retrieval, recommending decisions and preparing reports or presentation papers.

The infrastructure of IT is widely available today and it is in open system mode. Small companies have the ability to compete with large organizations with the accessibility of internet and e-business. The IT infrastructure has it foundation and most companies can enjoy it with minimal cost. With the IT infrastructure well placed, organizations can make available the management accounting information to the internal and external parties via internet.

Shareholders and investors are insisted to view the information of the organization's accounting results before deciding further investment. Management accounting also has resorted to IT infrastructure to gather information from various applications and database to manipulate the data and to produce reports for decision-making. Multi-national companies have optioned to IT to retrieve data from department and regional offices located worldwide.

IT in management accounting has its potentials in the future as current generations are exposed to IT and nowadays computers have been introduced during school days. IT skills are being possessed by younger generations and it will contribute and motivate the implementation of IT in every aspect of business including management accounting. CIMA, the management accounting body have initiated Business Information Systems syllabus for the management accounting students. This is to ensure that the future accountants not only able to use management accounting technologies but also contribute to the growth of IT in management accounting.

Small organizations do not have to develop in-house management accounting software as it may burden the organization's budget. Small organizations can take advantage of evolution of management accounting technology that is getting off-the-shelf management accounting packages. As such, small companies would be able to enjoy the management accounting technology with more affordable cost. $[15,16]$

\section{APPLICATION OF IT IN MANAGEMENT ACCOUNTING - THE BENEFITS}

The application of IT in management accounting brings benefits to the organization. There is evidence that technology adapted in management accounting is able to revoke the traditional management accounting limitations. IT and management accounting has merged as a system to provide essential information to organization's growth and smart investment. [17]

The data and information provided by the management accounting system is accurate and valid. The system is able to gather data and information from various resources or departments using data mining technology. The data mining technology uses single database repository that stores various information needed by the accounting system. As such, the budget or cost information provided to the management for decision making is deemed as accurate and real time.

During traditional accounting, the response for management accounting information may take weeks but with application of IT, the information is ready immediately. The technology is capable of processing large number of data and also to performs multi-tasking to achieve the desired result. Current technologies also allow users to choose the design of the reports wanted with a few mouse clicks. Management accounting systems are also capable of producing 3D charts for presentations. Most of the systems are user-friendly and easy to use. [18]

The management accounting system is able to provide various solutions for decision makers. IT can be designed to give recommendations and remedies to the management. The management accounting system is capable of calculating the payback period, ROI or breakeven point within split of seconds and advises the management on the decision to be taken. The technology is very much useful to management when they are planning or forecasting a long-term investment. The system is able to provide historical data and the market trends to the management to assist to make the correct and wise decisions.

It is rewarding to have technology in place for management accounting, as it will ease the accountant's responsibilities. The accountants now can focus on other important tasks such as financial analysis, decision making, consulting the management and design business models. [19]

This is because application of IT in management accounting releases accountants' from day to day-monotonous tasks involving data collection, calculation and reporting. The system can be designed to perform the said tasks and allow management and financial accountants to concentrate on more productive responsibilities.

The main gain of application of IT in management accounting is getting a competitive advantage. The internet plays a vital role for providing technology benefits to the organizations.

Companies can use the technology to draw customer's attention which ultimately benefits the growth of the company. IT in management accounting allows immediate updates of the information in the Web site so that the customers, investors and creditors are able to see a clear 
picture of the organization's plans and goals.

It is noted that the application of IT in management accounting have clearly resulted in benefits to the organization and more and more organizations are adapting IT in management accounting. [20,21,22]

\section{APPLICATION OF IT IN MANAGEMENT ACCOUNTING - THE IMPACT}

Application of IT in management accounting has major impact on the organization's profits. It is wrong to conclude that implementation of new technology in management accounting will improve company's profits. Implementation of new technologies may reduce company's income, as the implementation is costly depending on the technology adopted. There is a risk to the companies that if inappropriate technology is chosen, then the company is forced to incur unnecessary costs which lead to waste of resources. However, if the management and the accountants study the feasibility and the functionality of the systems before the implementation of IT in management accounting, then the above risk can be avoided.

The skill and knowledge of accountants should be repositioned to support the application of IT in management accounting. The companies have to send their staff to IT related training to acquire and update their IT skills to use the system efficiently. The users of the system must be trained well in order to take advantage of the technology within the system. Selecting user-friendly system is essential, as it require less IT skilled personnel to handle the system. Most of the systems available now are user-friendly and easy to use.

Technology is changing fast and it is very difficult to keep track with the technology changes. [23]

The company's challenge is to adopt a technology that can be used for a long period which may not be achievable now. The new technology today will be obsolete within couple of months and will be replaced by more sophisticated technology. So the company has to select the technology that is upgradeable to meet the future technology requirement.

\section{LIMITATIONS}

Due to the short research period, one of the key weaknesses of this article is that it failed to review the implementation of IT in individual management accounting module such as budget, standard costing and responsibility center. This article only provides studies of general factors affecting IT in management accounting. This article also did not explore in detail on the cost of IT implementation in management accounting. The various problems, confusions and drawback of using IT in management accounting stir up the question for additional research. The list and explanation on the technologies available in the market has been exempted and require further investigation. The relationship and understanding between the company and technology vendors have been unreciprocated. Other factors relating to selection of the appropriate technology and system by the management should be considered. [24]

\section{CONCLUSION}

It is acceptable to companies that application of IT in management is inevitable and many companies already looking towards implementation of IT based management accounting. Considering the paper-less environment, companies are tempted to exploit technology to reduce costs and overhead. However, the selection of appropriate system and technology is essential and vital, so that waste of money and resource do not arise.

By adopting correct system and technology in management accounting, the companies and the accountants are able to produce accurate reports to make decisions and investments. The application of IT in management accounting is becoming essential part of accounting to cater to the current needs of immediate business analysis and performance measures. [25]

It is undeniable that there are much potential for IT to be incorporated in management accounting. The current world is living on technology and no doubt, management accounting needs technology to improve and enhance its functionality. The managers are depending on IT to deliver the requirement that traditional management failed to provide.

Technology is vast changing and keeping track with the changes is a challenge to the company. The cost of implementation of the system is always a question because it is a non-profit supportive investment. The benefits can't be seen in cash terms. However, the management can choose the system and technology according to their budget.

Overall, applying technology in management accounting is in optimistic direction by the management in which they can benefit in terms of advantages provided by the technology. The close involvement by the management, accountant and users in implementing technology in the company in management accounting is much needed. At the end, it is to benefit everybody from shareholders, management and workers.

\section{REFERENCES}

[1] Anastas, M. (1997). The changing world of management accounting and financial management. Management Accounting. Pg. 48-51.

[2] Boggs, S.M. (2003). Accounting - the digital way. Retrieved from September 8, 2011 from http://www.knowledgestorm.com/business_accountning

[3] Burns, J., Scapens, R. and Turley, S. (1996). Some further thoughts on the changing practice of management accounting. Management Accounting. Pg. 58-60.

[4] Collier, A. (1999). The potential of E-Commerce. Retrieved July 18, 2011 from http://www.accaglobal.com [Connor N. \& Martinsons M.(2006). Management of information systems: Insights from accounting research. Informations \& Management, 43. Pg. 1014-1024.

[5] Cooper, B. (2002). The Accountant of the future. Retrieved July 18, 2011 from http://www.accaglobal.com

[6] Couzens, M.(2003). The value of website. Retrieved September 23, 2011 from http://www.accaglobal.com

[7] Dechow N., Granlund M. \& Mouritsen J. (2007).Management Control of the Complex Organization: [Relationships between Management Accounting \& Information Technology. In: C. Chapman, et al (eds). Handbook of Management Accounting Research. Elservier, Lda. Pg. 625-640. 
[8] Gilman, M. (2003). Nuggets and data mining. Retrieved July 12, 2011 from http://www.data- mine.com

[9] Gray, G.L. (2001). Financial reporting on the Internet instant economical, global communication. Retrieved August 19, 2011 from http://www.IFAC.com

[10] Granlund, M.(2007). On the interface between management accounting and modern IT - a literature review and some empirical evidence. Working paper, Turku School of Economics.

[11] Hemmer, T., \& Labro, E.(2008). On the optimal relation between the properties of managerial and financial reporting systems. Journal of Accounting Research 46. Pg. 1209-1240.

[12] Hurwitz, D. (2003). Enterprise portfolio management: The backbone of IT management and governance. Retrieved June 30, 2011 from http://www.niku.com Horngren, C. T. , Bhimani, A., Datar, S.M., \& Foster, G.(2005). Management and cost accounting, ( $3^{\text {rd }}$ ed.), Essex, UK: Pearson Education.

[13] Ittner, C.D., Larcker, D.F., (2001), Assessing empirical research in managerial accounting: a value-based management perspective. Journal of Accounting and Economics 32. Pg. 349-410. Kay, D. (2003). A balanced scorecard for customer support. Building the business case for improving problem resolution. Retrieved June 20, 2011 from http://www.dbkay.com

[14] Lambert, R.A., (2007), Agency theory and management accounting research. In: Chapman, C.S., Hopwood, A.G., Shields, M.D. (Eds.), Handbook of management accounting research, vol. 1. Elsevier, Amsterdam, pp. 247-268.

[15] Marriott, Marriott \& Selwyn. (2003). Information and communications technology in UK accounting education.
Retrieved from September 11, 2011 from http://www.accaglobal.com

[16] Meall, L. (2004). IFRS: Beyond mere IT compliance. Retrieved August 10, 2011 from http://www.accaglobal.com

[17] Nuclues Research Inc. (2003). ROI case study: Hummingbird public service New Mexico. Retrieved July 19, 2011 from http:/www.nucleusresearch.com

[18] Phillips, P. \& Kirby, D. (2002). The impact of electronic business on accountants: A shareholder value perspective. Retrieved August 12, 2011 from http://www.accaglobal.com

[19] Sayana, A. (2003). Using CAATs to Support IS Audit, Information System Control Journal (1). Pg. 21-23.

[20] Sacchi, G. (2003). Delivering business value through a service-oriented Architecture. Retrieved August 15, 2011 from http://softwareagusa.com

[21] Skidmore, S. (2002). Information Technology in the accounting curriculum. Retrieved May 10, 2011 from http://www.accaglobal.com

[22] Welfle, B. \& Keltyka, P. (2000). Global competition: the new challenge for management accountants. The Ohio CPA Journal, (Jan-March). Pg. 30-36.

[23] Wong, C. (2003). Computer resources on tap. ComputerWorld, Issue No 4. Pg. 14.

[24] Wong, C. (2003). Better financials. Audrey International Finds the Right Financial and Accounting Application to Improve Efficiency and Data Consolidation, ComputerWorld, Issue No 7. Pg.30-31.

[25] Yager, T. (2002). The show must go on. ComputerWorld, Issue No 9. Pg. 15-16. 